IRSH 55 (2010), pp. 4I3-446 doi:10.1017/So020859010000I 80

(C) 2010 Internationaal Instituut voor Sociale Geschiedenis

\title{
State-Led Agricultural Intensification and Rural Labour Relations: The Case of the Lilongwe Land Development Programme in Malawi, I968-ı98 I*
}

\author{
ERIK GREEN \\ Department of Economic History, Stockholm University \\ E-mail: Erik.Green@ekohist.su.se
}

SUmmary: This article deals with cash crop production and its impact on labour relations in postcolonial African peasant agriculture. The focus is on the Lilongwe Land Development Programme (1968-198I) in Malawi. The aim of the programme was to enable African farmers to increase yields and make them shift from the cultivation of tobacco and local maize to groundnuts and high-yielding varieties of maize. The programme failed to meet its goals, because of contradictory forces set in motion by the programme itself. The LLDP enabled a larger segment of farmers to engage in commercial agriculture, which caused a decline in supplies of local labourers ready to be employed on a casual or permanent basis. Increased commercial production was thus accompanied by a de-commercialization of labour relations, which hampered the scope for better-off farmers to increase yields by employing additional labourers. By using both written and oral sources, this article thus provides an empirical case that questions the conventional view that increased cash-crop production in twentieth-century rural Africa was accompanied by a commercialization of labour relations. It concludes that the history of rural labour relations cannot be grasped by simple linear models of historical change, but requires an understanding of local contexts, with a focus on farming systems and factors that determine the local supply of and demand for labour.

\footnotetext{
* Previous versions of this article were presented at the African Economic History Workshop at the London School of Economics. I am grateful for the constructive comments of the participants. I especially want to thank Dr Gareth Austin (LSE) for sharing his insights and ideas. The comments received from the two anonymous reviewers for this journal were also highly appreciated. The findings of this article are based on fieldwork carried out in Malawi; that fieldwork would not have been possible without the great support of the staff at the Malawi National Archives, of my assistant Chikondi Banda, as well as of Dr C.M. Masangano at Bunda College of Agriculture. The research was supported by a grant from the Swedish International Development Cooperation Agency's research council.
} 


\section{INTRODUCTION}

Just a few years back, Malawi was often described as a failure in terms of agricultural development. Agricultural production fluctuated considerably and years of food deficits were common. The situation has dramatically improved since 2006. Malawi has moved from being dependent on the United Nations World Food Programme to having a food surplus. Many experts point to the importance of state intervention in this process, more precisely the reintroduction of subsidies for chemical fertilizers in 2005. Meanwhile, there are indications that labour relations in rural Malawi are undergoing major changes. In the aftermath of the famine of 2002 and in the light of the current HIV/AIDS crisis, more farmers have become dependent on providing casual labour. ${ }^{\mathrm{I}}$ A crucial, and perhaps provocative, question is whether the increased supply of casual labourers is facilitating the growth in production. Labour plays a crucial role in African farming systems. Strategies to increase production, either through an extension of the area of land under cultivation or an intensification of land use, depend on the ability to mobilize increased quantities of labour. A study of those strategies requires a more detailed analysis of labour relations in rural Africa from a longitudinal perspective and of how changes in the demand for and supply of labour have affected the trajectories of agrarian change.

This article provides such an analysis. It focuses on a historical case of state intervention which redirected the paths of agrarian change by altering labour relations. The case under investigation is the Lilongwe Land Development Programme (LLDP) of I968-I98 I, in central Malawi (see Figure I). The overall aim of the programme was to increase yields per unit of land and to create incentives for farmers to reallocate land from local maize and tobacco production to the production of groundnuts and high-yielding varieties of maize. It failed in both respects. ${ }^{2}$

That failure has to be understood in relation to the unintended consequences of the programme. By the late i95os Lilongwe district had the largest concentration of cash-crop-producing peasants in Malawi. The cash-cropping farmers depended on a wide range of labour arrangements, including casual and permanent wage labour. The LLDP enabled an even greater number of farmers to engage in commercial agriculture. At the

I. Deborah Bryceson, "Ganyu Casual Labour, Famine and HIV/AIDS in Rural Malawi: Causality and Casualty", Journal of Modern African Studies, 44 (2006), pp. 173-202.

2. Funding for the programme was cut in $198 \mathrm{I}$, but not because it was considered a failure. It had been decided at the outset of the programme that funding would be phased out in the early I 980 s in the expectation that by then the farmers would be able to manage without further assistance. The critical reports of the Lilongwe Land Development Programme were published a few years after funding had been cut. It was then, for the first time, that the LLDP began to be described in terms of failure. 


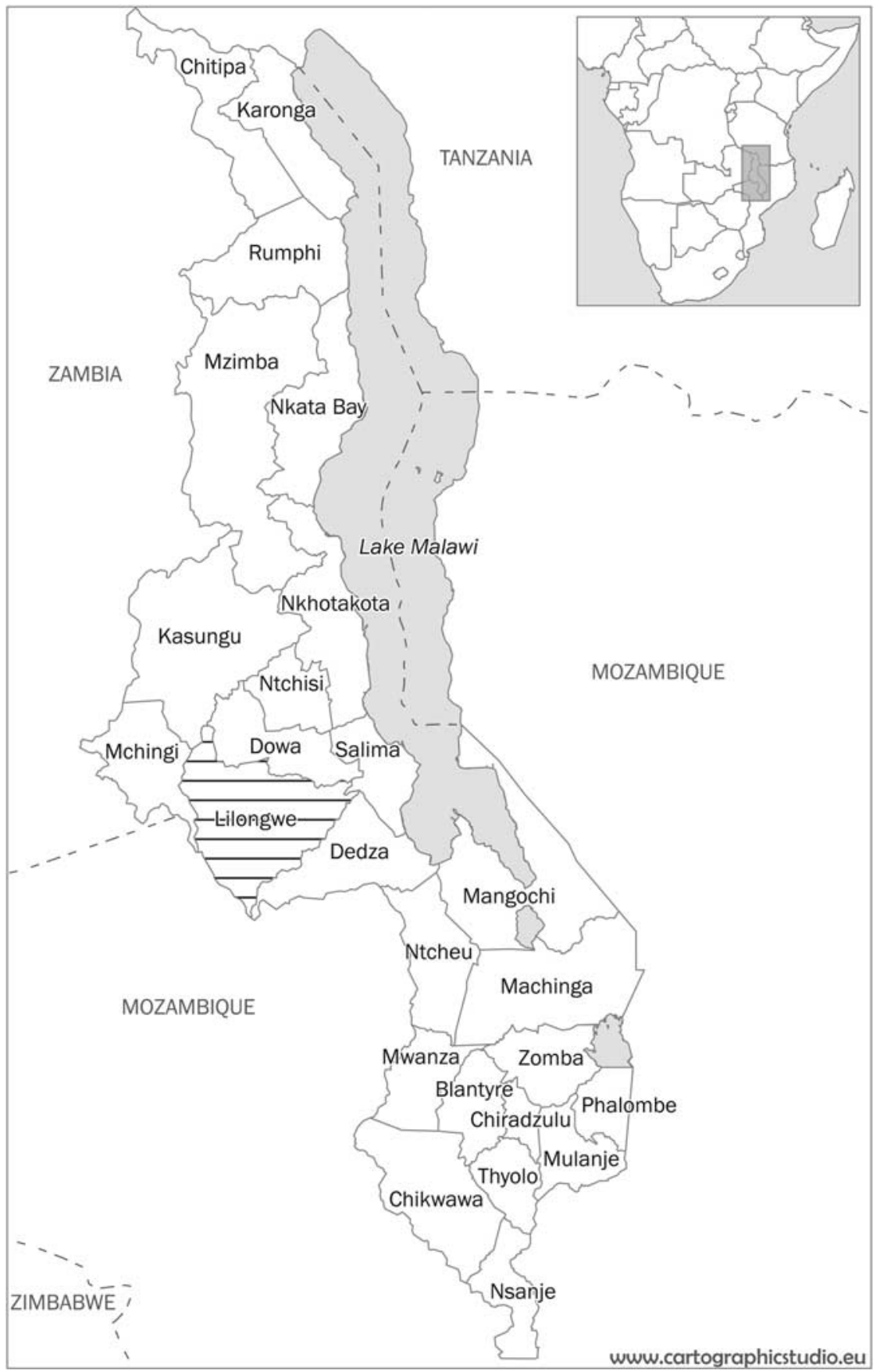

Figure I. Map of Malawi and its district boundaries. 
same time, the diffusion of commercial cultivation led to a decline in supplies of labourers since a larger number of farmers shifted from selling their labour to growing cash crops themselves. It became increasingly difficult to employ local casual and permanent labourers. Farmers who had earlier hired casual and permanent labourers were left with two options, either to intensify labour arrangements based on reciprocity that is, intensify the use of collaborative arrangements - or to search for labour on markets outside the district. The latter was expensive and an option only for a few richer farmers. The former became increasingly important and the arrangements were subsumed to the needs of commercial agriculture, leading to a strengthening of reciprocity in the contracts. Still, the collaborative arrangements were not efficient in terms of managing to increase yields of maize and groundnuts.

A rather different story is provided by the continuous expansion of tobacco production throughout the duration of the programme. This development was contradictory not only to the aim of the project but is also difficult to explain in the light of the shortages of wage labourers. The expansion of tobacco production is explained by the rise of informal trade in tobacco seeds caused by the introduction of tobacco quotas in 1968. Again, it was an unintended consequence of state regulation. Certified owners who lacked the means to meet their quotas gave seeds to farmers who cultivated the crop in their own field. The certificate holder then sold the crop and the two parties shared the profit. Mandala discovered a similar pattern in southern Malawi, where the state provided certified cotton growers with pesticides and sprayers through the Shire Valley Agricultural Development Project (1968-1978). ${ }^{3}$ Cotton farmers with relatively large landholdings occasionally chose to trade some of the sprayers and pesticides with their poorer neighbours. Sprayers were leased while the pesticides were sold. ${ }^{4}$ Mandala argues that this was part of a strategy of risk aversion in times of unstable weather conditions and low producer prices. We would claim that the exchange of seed was directly linked to the question of labour allocation. It created a redistribution of capital (seeds) to where it could be most productively used in a context of decreasing supplies of casual and permanent wage labour.

It must be stressed that the present article is not an exercise in project evaluation. Using the Groundnut Scheme in Tanganyika (I946-I952) as an example, Rizzo rightly argues for the need to move beyond intended outcomes in order to reveal the impact of a specific programme. He shows how the scheme failed to meet its intended targets of increased production,

3. In its initial phase (1968-1973) the Shire Valley Agricultural Development Project was known as the Chikwawa Cotton Development Project.

4. Elias Mandala, The End of Chidyerano: A History of Food and Everyday Life in Malawi, I860-2004 (Portsmouth, NH, 2005), p. I 56. 
but simultaneously created an expanded local labour market that absorbed the rural population in the area. ${ }^{5}$ Thus, there is a risk of neglecting the long-term effects of a project when historical evaluations are based solely on intended outcomes. In this article, however, the LLDP is used as a starting point for a wider discussion about state intervention, agricultural commercialization, and rural labour relations. For this purpose, a narrow focus on yields is a useful entry point, enabling us to analyse changes in labour relations over time and how those changes affected specific farming systems.

We have drawn on archival sources obtained from the Malawi National Archives that were made available in 2006. The quality of the sources is comparatively good; they include information on yields and, to some extent, farming methods. However, one fundamental problem with the archival records is that they are based on the assumption that most farmers rely only on family labour. Oral information has therefore been used to complement the archival material. Interviews were conducted in units 3-9, I 2-I 5, and 23 (the LLDP was divided into units, see Figure 2), in what today form part of the Mkwinda, Ukwe, Malingunde, and Mpingu Extension Planning Areas. ${ }^{6}$ The sites were selected on the basis of a single factor, namely the extensive cultivation of tobacco particularly in the I960s. Those were areas therefore in which commercial production was common before the establishment of the LLDP. Oral information was gathered using semi-structured interviews focusing on labour allocation. They do not reveal precise changes on a year-to-year basis. Nor do they uncover the exact magnitude of change. The information should be treated with caution; it forms merely the basis of a tentative discussion.

5. Mattoe Rizzo, "What Was Left of the Groundnut Scheme? Development Disaster and Labour Market in Southern Tanganyika 1946-1952", Journal of Agrarian Change, 6 (2006), pp. $205-238$.

6. A total of 36 farmers were interviewed individually while 35 chiefs and village headmen were interviewed in groups (see Table I). The farmers were divided into 3 groups, following the project management organizing principle of social division, according to the size of landholdings. In 1975 , half way through the project, the average size of landholdings was calculated to be 4.5 acres, with io per cent cultivating more than 7.5 acres and 25 per cent about 2-3 acres. See Bill Kinsey, "Growth, Equity and Integrated Rural Development in Malawi: Selected Lessons From a Decade and a Half of Project Experience", Discussion Paper No. I 3 I, School of Development Studies, University of East Anglia (1983). We adopted this division but assumed that the different systems of allocating labour would play a much more important role than assumed by the management. To the above categories we added a group of female-headed households that to a great degree did not grow any cash crops. The latter group was difficult to identify and we quickly decided that the absence of a male head in the I970s (due either to the death of the husband or his absence because he was a migrant worker) should be the only organizing principle. Among this category we therefore find small and large landholders. In addition, a sub-group of women who engaged in growing tobacco by using the certificate of someone else was also interviewed. 


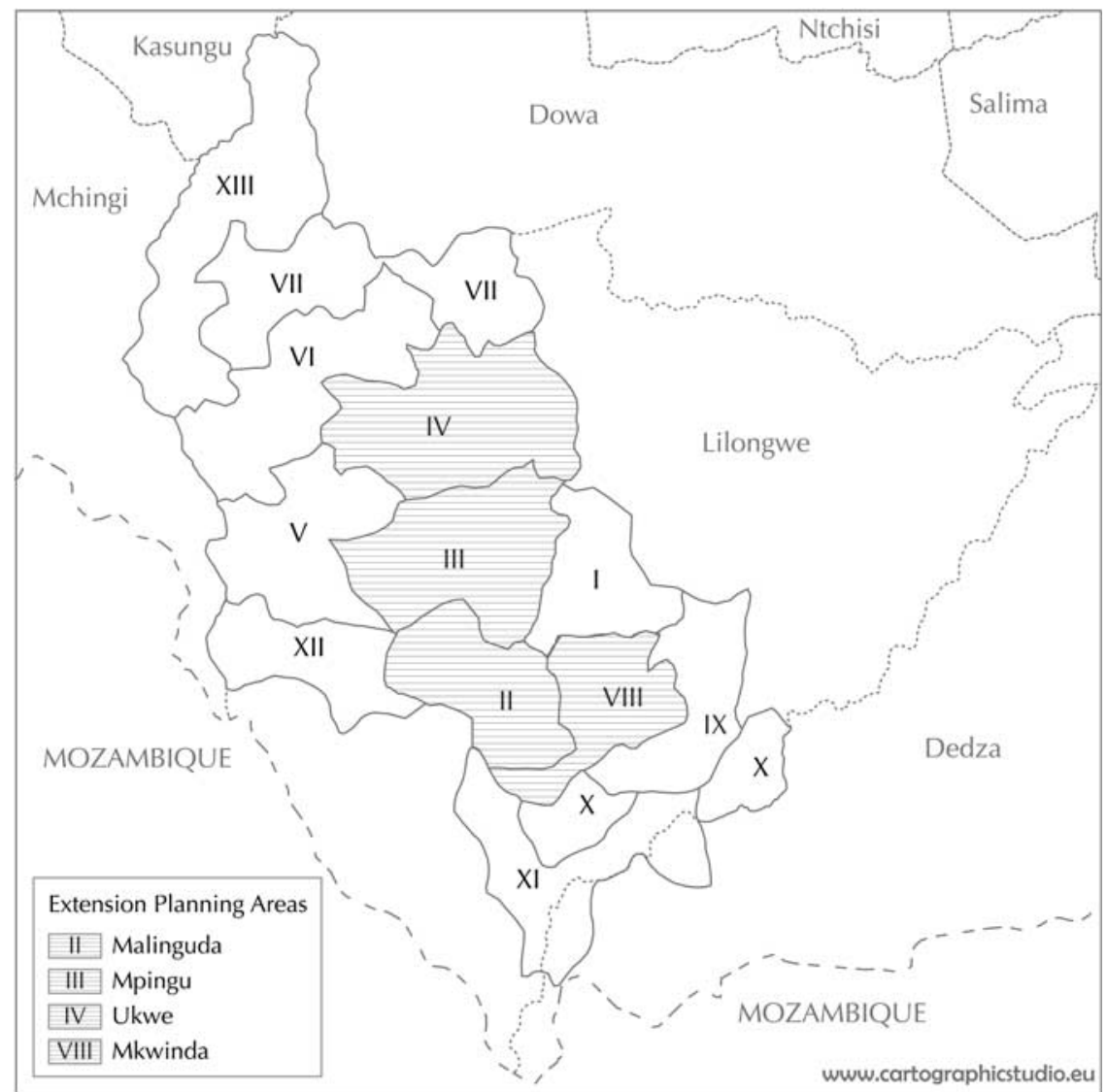

Figure 2. Map of extension planning areas in Lilongwe district, I 977.

\section{STATE INTERVENTION, AND LABOUR RELATIONS IN AFRICAN AGRARIAN HISTORY}

The impact of state intervention on agrarian commercialization in general and on labour relations in particular in twentieth-century rural Africa is a broad topic that has received a lot of attention over the years. Historical studies (excluding those on South Africa) have dealt mostly with the late colonial period and the common argument is that state intervention that aimed at increasing the number of farmers engaged in commercial agriculture reinforced social differentiation, although this seldom led to a transformation of labour relations. ${ }^{7}$

7. See for example Owen Kalinga, "The Master Farmers' Scheme in Nyasaland, 1950-1962: A Study of a Failed Attempt to Create a 'Yeoman' Class", African Affairs, 92 (1993), pp. 367-387; 


\section{Table I. Number of interviews, by geographical area and gender}

\begin{tabular}{lcc}
\hline $\begin{array}{l}\text { Extension } \\
\text { planning area }\end{array}$ & $\begin{array}{c}\text { Total number of chiefs/village } \\
\text { headmen in group discussions } \\
\text { (number of women) }\end{array}$ & $\begin{array}{c}\text { Total number of farmers } \\
\text { interviewed individually } \\
\text { (number of women) }\end{array}$ \\
\hline Mkwinda & $11(0)$ & $14(7)$ \\
Ukwe & $11(2)$ & $8(6)$ \\
Mpingu & $7(1)$ & $4(0)$ \\
Malingunde & $6(1)$ & $10(5)$ \\
\hline
\end{tabular}

The impact of state intervention in the early postcolonial period has been given less attention despite the general intensification of state-led rural development programmes. An important development during the period was the establishment of the integrated rural development programmes (IRDPs). Those programmes marked the most comprehensive attempts in the modern history of Africa to influence rural communities and promote agricultural growth. Studies of IRDPs in Africa have focused mainly on factors exogenous to farming systems, such as the lack of capacity among the project designers and implementers, inefficient delivery systems, and coordination problems. ${ }^{8}$ There are some exceptions. In their study of IRDPs in Zambia, Fenichel and Smith concluded that the programmes increased differentiation and spurred the growth of a group of wealthier farmers who employed wage labourers. ${ }^{9}$ Cohen's study of integrated rural development projects in Ethiopia reached a partly different conclusion. $\mathrm{He}$ too argued that the projects increased differentiation, but, and more importantly, also that they failed to break the semi-feudal structures of the societies. ${ }^{10}$ Thus, the effect of the IRDPs on labour relations in rural Africa is uncertain.

Empirical studies reveal that rural labour relations in Africa, Asia, and Latin America are not easily grasped using rigid categories of free and

Sara Berry, No Condition is Permanent: The Social Dynamics of Agrarian Change in SubSaharan Africa (Madison, WI, I993), pp. 43-66; Henrietta Moore and Megan Vaughan, Cutting Down Trees: Gender, Nutrition, and Agricultural Change in the Northern Province of Zambia, I 890-I990 (London, I994), pp. I I0-I 39; Wazha G. Morapedi, "The State, Crop Production and Differentiation in Botswana, 1947-1966", Journal of Southern African Studies, 32 (2006), pp. $35 \mathrm{I}-366$.

8. Hans Binswanger, "Agricultural and Rural Development: Painful Lessons", in John Staatz and Carl K. Eicher (eds), International Agricultural Development (London, I998), pp. 287-299; Vernon W. Ruttan, "Integrated Rural Development Programmes: A Historical Perspective", World Development, I2 (1984), pp. 393-40I.

9. Allen Fenichel and Bruce Smith, "A Successful Failure: Integrated Rural Development in Zambia”, World Development, 20 (1992), pp. I3 I3-I323, I3 17.

Io. John M. Cohen, Integrated Rural Development: The Ethiopian Experience and the Debate (Uppsala, I987), pp. I I I-I37. 
unfree labour. The history of labour is not a unilinear process with unfree labour being replaced by free wage labour. The concept of free wage labour should instead be treated as an ideal type rather than a category of historical reality. ${ }^{\text {II }}$ In line with these arguments, most historians agree that the developments in twentieth-century rural Africa cannot be characterized in terms of the separation of producers from the means of production. Family farms remain the dominant form of production. Yet this does not imply that family labour had been the only source of labour. On the contrary, the historical evidence shows that it had often been supplemented with labour allocated through social networks and markets. ${ }^{\mathrm{I2}}$ The increased dependency on several different labour arrangements was a significant characteristic of African farming systems in the twentieth century.

Meanwhile, historians have argued that the reliance on wage labourers increased over time due to the commercialization of agricultural production. That conclusion is often based on cross-sectional comparisons. ${ }^{{ }^{3}}$ Using a longitudinal approach, evidence reveals that rather than being the final stage of a linear development, the use of wage labourers fluctuated over time. A classic example is the rise and fall of wage labour (c.1910-1930) among cocoa growers in southern Ghana and how it was replaced by sharecropping arrangements. ${ }^{14}$ In his discussion about the Ghana case, Austin argues that sharecropping replaced wage labour because it reduced the risks to both the employer (of paying high wages in years of failed harvest or low prices) and the employee (of not getting paid at all in bad years). It was a strategy to reduce risk, both for the employers and employees, by avoiding market fluctuations. ${ }^{\text {is }}$

A focus on allocation, and a recognition that several different labour arrangements have coexisted, allows for a more precise analysis of how different labour arrangement have complemented and/or substituted each other in order to maximize output. Each crop differs not only in terms of required labour input, but also when the labour is needed, how quickly it is needed, and the kinds of skill required. For example, timing is more important in the cultivation of high-yielding varieties of maize compared with local varieties. ${ }^{16}$ Cultivation of tobacco requires access to labourers who

I I. Willem van Schendel, "Stretching Labour Historiography: Ideas from South Asia", International Review of Social History, 5 I (2006), Supplement, Coolies, Capital and Colonialism: Studies in Indian Labour History, pp. 229-26I, 229-230.

12. Gareth Austin, Labour, Land and Capital in Ghana: From Slavery to Free Labour in Asante, 1807-1956 (New York, 2005); Bill Freund, The African Worker (Cambridge, 1998); John Iliffe, The Emergence of African Capitalism (London, 1983).

13. See for example Berry, No Condition is Permanent, p. I39.

14. Austin, Labour, Land and Capital in Ghana, pp. 304-321; Iliffe, Emergence of African Capitalism, pp. 24-28.

I s. Austin, Labour, Land and Capital in Ghana, pp. 304-321.

16. Berry, No Condition is Permanent, p. I46. 
have the skills needed to remove the flower buds and cure the leaves properly. It is in this respect that we have to understand why African farmers depended on a wide range of labour arrangements in the twentieth century.

In the short term additional labour is more easily mobilized through commercial labour relations than collaborative (reciprocal) arrangements, since the latter arrangements require long-term investments in social networks. But commercial labour relations are less flexible than older systems of slavery and pawning, where labourers were "always available". ${ }^{17}$ The latter explains why farmers who became increasingly dependent on wage labour occasionally attempted to reproduce patterns of social subordination. In the I920s and I930s, cocoa growers in Ghana often employed the same people year after year and allowed the workers to live and eat with them. ${ }^{8}$ By doing so, they ensured that the labourers could be mobilized quickly. Hiring permanent wage labourers also has the advantage of enabling employers to select people with the right skills. Yet, only a few African farmers have had the means to employ permanent wage labourers. Instead, casual labour, paid in cash or kind, has played a far more significant role in African farming systems.

The allocation of casual labourers is an equally relatively flexible system in terms of mobilizing additional labour on a short-term basis, but it is associated with a high degree of risk. Casual labourers are not tied to a specific employer, and the supply of labourers fluctuates over time due to exogenous factors that individual farmers can seldom influence. Berry, for example, has argued that during the latter half the twentieth century it became increasingly difficult for African farmers to access and control casual labourers, as farm workers shifted their income sources to the offfarm sector and/or began to grow cash crops themselves. ${ }^{19}$

Turning our focus to Malawi, it is notable that most historians have focused their research on the demand for and supply of labourers on the European-owned estates. ${ }^{20}$ Studies of labour relations on peasant farms have concentrated mainly on different strategies to mobilize and control labour within the household. ${ }^{2 \mathrm{I}}$ There are some notable exceptions to this

\section{Ibid.}

18. Ibid., p. I44.

19. Ibid., pp. 145. I48. For an example of the difficulties of finding casual labourers in the Malawi context, see Erik Green, "Labour Costs and the Failed Support of Progressive Farmers in Colonial Malawi: A Tentative Discussion”, paper presented at the Science, Technology and Environment in Africa Conference, 27-29 March 2009, University of Texas, Austin.

20. Wiseman Chijere Chirwa, "Alomwe and Mozambican Immigrant Labor in Colonial Malawi, I 890-1 945”, International Journal of African Historical Studies, 27 (1994), pp. 52 5-550; Robin Palmer, "White Farmers in Malawi: Before and After the Depression", African Affairs, 84 (1985), pp. 21 I-245; idem, "Working Conditions and Worker Responses on Nyasaland Tea Estates, 1930-1953", Journal of African History, 27 (1986), pp. 105-I 26.

21. See, for example, Elias Mandala, "Peasant Cotton Agriculture, Gender and Inter-generational Relationships: The Lower Tchiri (Shire) Valley of Malawi, 1906-1940", African Studies 
pattern. Historians including McCracken and Mandala have depicted the existence of wage labour employed by a peasant "elite" involved in cash-cropping during the twentieth century in southern, central, and northern parts of Malawi, including Lilongwe district. ${ }^{22}$ They argue, directly or indirectly, that the emergence and diffusion of wage-labour arrangements were linked to the growth of cash-cropping. Mandala, for example, claims that "cotton farming in the valley acted as an important catalyst in the emergence of wage-labor relations in the peasant sector". ${ }^{23}$ That quotation reveals an underlying assumption about the history of labour as a linear process, with the growth of commercial agriculture being accompanied by increased use of wage-labour arrangements.

Yet the authors do not discuss why richer cotton and tobacco growers found it beneficial to hire wage labour in the first place. More importantly, the role of wage labourers is not analysed from a longitudinal perspective. It is therefore not possible to draw any conclusions about the linkages between commercial production and labour relations over time. Below, we will present a case that contradicts the assumption that an expansion of cashcrop production automatically leads to increased use of casual and permanent wage labourers. Instead, farmers continued to rely on a wide variety of labour arrangements. A notable change, though, was that by enabling an increasing number of farmers to engage in commercial agriculture the LLDP also created shortages of local labourers who could be employed on a casual or permanent basis. The decline in the supply of local labourers left farmers increasingly dependent upon collaborative labour arrangements. These were subsumed to the needs of commercial agriculture and adapted to the decreased supply of labourers by a strengthening of reciprocity in the labour contracts. Agricultural commercialization was thus accompanied by a rise in reciprocal labour arrangements.

\section{THE ESTABLISHMENT OF THE LLDP}

Lilongwe district is situated in the central region of Malawi and covers an area of 6,159 square kilometres. In the late i 960 s its population was $\mathrm{I}, 346,360$. The district is bounded to the west and the south by the watershed dividing the Luangwe and Zambezi valleys from Lake Malawi,

Review, 25 (1982), pp. 27-44; Megan Vaughan, "Food Production and Family Labour in Southern Malawi: The Shire Highlands and Upper Shire Valley in the Early Colonial Period", Journal of African History, 23 (1982), pp. 351-364.

22. Kalinga, "Master Farmers"; Elias Mandala, Work and Control in a Peasant Economy: A History of the Lower Tchiri Valley in Malawi, I859-1960 (Madison, WI, I990), pp. I38-I40; John McCracken, "Planters, Peasants and the Colonial State: The Impact of the Native Tobacco Board in the Central Province of Malawi”, Journal of Southern African Studies, 9 (1983), pp. $172-192$.

23. Mandala, The End of Chidyerano, p. 160. 
to the east by the lakeshore, and to the north by the line of latitude $13^{\circ}$ $30^{\prime \prime}$. Most of the area is part of the great plateau which extends along the western side of the lake. The area is fairly undulating terrain, with occasional steep slopes that descend sharply into small watercourses or dambos (wetland). The winter season (June-August) is comparatively cold and prevents the cultivation of long-term crops such as cotton, which has been a major cash crop for African farmers in Malawi's populous southern region. ${ }^{24}$

The district has been an important area for African commercial agriculture since the mid-I920s, when farmers began to cultivate fire-cured tobacco. Initially, tobacco-growing farmers were tenants who sold their produce to their landlord. However, subsequently an increasing number of farmers on Crown Lands (the latter mainly on the Lilongwe Plain) in Lilongwe and Dowa districts became independent producers. ${ }^{25}$ The expansion of tobacco production was helped by the favourable circumstances of fertile sandy soils and well-drained land, as well as the existence of combretum-acacia woodlands that could be used for curing the tobacco. ${ }^{26}$ By the late I950s, Lilongwe district had become the most important area in Malawi in terms of African production of maize, tobacco, and groundnuts. In fact, the district had the largest concentration of African cash-crop producers in the late 1950s. ${ }^{27}$ In 1967, there were 47,000 registered tobacco-growers in the district, producing 28 million pounds of tobacco leaves. ${ }^{28}$ The tobacco boom in the I950s was fuelled by a distinct group of wealthy farmers who employed both casual and permanent labour. ${ }^{29}$

24. Public Record Office, London [hereafter, PRO], Register CO 525, Folio I 59/17, The Agricultural Survey of Central Nyasaland, by A.J.W. Hornby, Assistant Director of Agriculture and Agricultural Chemist, 1935 .

25. PRO, Register CO 525, Folio I I I, Annual Report, Department of Agriculture, I 924.

26. McCracken, "Planters, Peasants and the Colonial State", p. 175; Tony Woods, "Why Not Persuade Them to Grow Tobacco': Planters, Tenants, and the Political Economy of Central Malawi, 1920-1940", African Economic History, 21 (1993), pp. I 3 I-I 50, I 32.

27. Jonathan Kydd, "Policies Towards Peasant Agriculture: A Case Study of the Lilongwe Land Development Programme, Malawi”, paper presented at a workshop at Chancellor College, Zomba, I4 April I984, p. 3.

28. Malawi National Archives, Zomba [hereafter, MNA], Box PCC File i/i s/6, Economic Survey of Lilongwe 1953 (Draft), MNA, Box 9/8, Tobacco Registration 1967/68: enclosed in Regional Agricultural Officer Lilongwe to Supervisors of the Farmers' Marketing Board.

29. There is no detailed research on this group of farmers, and archival resources do not reveal the number of farmers who employed permanent wage labourers. The best available proxy is to look at the number of appointed master farmers in the 1950s. The Master Farmers' Scheme was introduced as a national programme in $195 \mathrm{I}$ with the aim of identifying so-called progressive farmers who would be supported financial and educationally. Kalinga has shown that most of the farmers selected belonged to a group of relatively rich farmers who employed both casual and permanent wage labourers. In Lilongwe i2 I farmers were appointed master farmers 
It was this tradition of commercial production that induced the Agriculture Department to make Lilongwe district a special target. It was believed that it provided an area where it would be possible to facilitate the transition from semi-subsistence to a cash economy with a minimum of social disruption. ${ }^{30}$ While the area was recognized as having high potential, that potential was threatened by soil erosion and population pressure. The latter was believed to have speeded up the existing processes of land fragmentation and hence decreased the productive capacity of the area. It was hoped that this could be prevented by providing new technologies, investing in basic infrastructure, opening up new market depots, and intensifying agricultural extension services.

The LLDP has to be understood in the broader context of national development strategies. Malawi achieved independence in 1964. Its economic policies in the I970s rested on two central pillars, namely maintaining food production and maximizing foreign exchange earnings by expanding cash-crop production. ${ }^{3 \mathrm{I}}$ It was stressed that maintenance of food production should be based on increased yields rather than on an extension of the area of land under cultivation in order to allow for further expansion of cash-crop production. In the first five years of independence, Dr Hastings Kamuzu Banda, Malawi's first president and after 1971 elected President for Life, emphasized the role of peasant farmers as cash-crop producers. However, since Banda had managed to consolidate his power by the late i960s and the radical and populist elements had been thrown out of government, the focus shifted towards estates, which were granted monopoly rights to cultivate tea, sugar, barley, and flue-cured tobacco. ${ }^{32}$

It did not imply that peasant farmers were neglected. In fact, almost all government aid to the agricultural sector in the I970s was directed at peasant farmers, with the aim of maintaining food production apace with population growth. ${ }^{33}$ Yet, as cash-crop producers, African peasant

in 1959; this compares with $5 \mathrm{I}$ farmers in the populous southern province as a whole in 1956. This indicates that the group of wealthy farmers in Lilongwe was relatively large compared with the same group in other districts in Malawi. See McCracken, "Planters, Peasants and the Colonial State”, pp. I84-190; Kalinga, "Master Farmers", p. 376; and MNA, Box A/R Annual Report Lilongwe district 1959.

30. Kinsey, "Growth, Equity and Integrated Rural Development".

3 I. Megan Vaughan, "Exploitation and Neglect: Rural Producers and the State in Malawi and Zambia", in David Birmingham and Phyllis M. Martin (eds), History of Central Africa: The Contemporary Years since 1960 (London, I998), pp. I82-183.

32. Guy C.Z. Mhone, "Agriculture and Food Policy in Malawi: A Review", in T. Mkandawire and N. Bourename (eds), The State and Agriculture in Africa (London, 1987), p. 62; Vaughan, "Exploitation and Neglect", p. I 83.

33. Frederic L. Pryor and Chinyamata Chipeta, "Economic Development through Estate Agriculture", Canadian Journal of African Studies, 24 (1990), pp. 50-74, $5 \mathrm{I}$. 
farmers were generally regarded as unable to become the engine of economic growth. There were exceptions to this view. In a few selected geographical areas, it was decided to intensify support to African peasant farmers with the aim of promoting a sustained increase in yields of both food and cash crops. It was hoped that the farmers targeted would become role models for the peasant farmers in Malawi. The Lilongwe Land Development Programme was the most prominent of all the projects. The vision was to transform Lilongwe west into a model area of highly productive and commercially oriented small-scale farming. ${ }^{34}$

At the outset of the programme, the average population density was estimated at 34I persons per square kilometre - a fairly high figure. The continent has often, at least until recently, been portrayed as land abundant, with an average population density of approximately 23 people per square kilometre in the I960s. ${ }^{35}$ In Lilongwe, on the other hand, labour was in abundance while land was scarce, i.e. land-labour ratios were low. The population was nevertheless unevenly distributed, as it was influenced by the topology of the land and by water supplies. ${ }^{36}$ In 1975 , it was calculated that an average family consisted of 4.5 people who cultivated approximately 6.7 acres on land strips spread over a larger area, although access to land varied greatly among households. ${ }^{37}$ It was estimated that in the mid-r970s about half of the population in the area had access to both dry-land (munda) and wetland (dambo) gardens. Nearly all households grew local varieties of maize and groundnut. The cultivation of sweet potatoes and green beans was also relatively widespread, while about half of households focused on tobacco production. ${ }^{38}$ Following Boserup's classification, we can conclude that most farmers practised labour-intensive methods of annual cropping and/or grass fallow. ${ }^{39}$

34. World Bank, Malawi Lilongwe Land Development Program Phase III: Project Performance Audit Report (Washington DC, 1981).

35. Gareth Austin, "Resources, Techniques, and Strategies South of the Sahara: Revising the Factor Endowments Perspective on African Economic Development, I 500-2000”, Economic History Review, 6I (2008), pp. 587-624.

36. Clement Ng'ong'ola, "The Design and Implementation of Customary Land Reforms in Central Malawi”, Journal of African Law, 26 (1982), pp. II5-132; R.A. Reader, A SocioEconomic Survey of Agriculture in the Lilongwe Land Development Program Area, Part I: The Structure of Smallholder Agriculture (Zomba, I97I).

37. MNA $14 / 20 / \mathrm{I}_{3} / 7$, A Survey of Tobacco Production in the Lilongwe Land Development Programme Area, 1972/73-1974/75.

38. Anita Spring, Agricultural Development and Gender Issues in Malawi (Boston, MA, I995), pp. I 29-I3I.

39. Boserup's classification does not reveal the precise amount of labour needed for each farming system. But it can be used to understand the relative change in labour inputs and is therefore valid given the lack of data on labour inputs. All fallow systems, except for tree fallow, require weeding, and data from experimental stations in British Africa reveal that weeding in general requires more labour per hectare than the heavy work of clearing forest land. In 
Ridge cultivation was prevalent, with undulating ridges of mainly sandy loams. ${ }^{40}$ However, unlike in the southern region of Malawi, farmers did not construct ridges on an annual basis. Instead, planting was done on the old ridges. Land was prepared by clearing the old ridges of old maize stalks and dry grass, which were then placed between the ridges. ${ }^{4 \mathrm{I}}$

In 1967, the government agreed with the World Bank to establish an integrated rural development project in the western part of Lilongwe district. It covered I.I million acres lying west of Lilongwe, Malawi's capital city. The area was divided into 40 administrative units of approximately 8,000 acres each. Around 2,600 farming families lived in each unit. Units had a service centre which contained the headquarters of the unit extension and the produce market. ${ }^{42}$ The project was divided into 4 phases and it was believed that with support in the form of capital, technology, and infrastructure, the area would experience a "take-off" into sustained growth after the first 5 years. ${ }^{43}$

The most important aim of the LLDP was to increase yields per unit of land. The emphasis was placed on maize and groundnuts, in the hope that the two cash crops would partly replace tobacco, since it was believed that cultivation of the latter had a damaging effect on soil fertility. It was intended to achieve increases in the productivity of maize-growing through a technical package, which included fertilizers and seed from improved varieties, and intensive extension work. ${ }^{44}$ The latter consisted of education in ridge construction, early planting, weeding, and careful spacing. On the other hand, yields of groundnuts were supposed to increase merely through changes in farming methods, i.e. early clearing, preparation, and planting of gardens, as well as the correct spacing of plants. ${ }^{45}$ None of the advice was

addition, shorter periods of fallow demand more labour for the preparation of gardens, since land has to be more carefully cleared without the help of fires. See Ester Boserup, The Conditions of Agricultural Growth: The Economics of Agrarian Change under Population Pressure (London, 1965).

40. Andrew M. Mercer, The Lilongwe Development Programme: Activities with Some Comments on Populace Participation (Zomba, 1972); Reader, A Socio-Economic Survey of Agriculture.

4I. MNA, Box 9/8, Minutes of a meeting of the District Development Committee together with all chiefs and leaders of the District Malawi Congress Party, 21 October 1966.

42. Ng'ong'ola, "The Design and Implementation of Customary Land Reforms", p. I 22.

43. The first two phases (1968-1975) focused mainly on crop production. In the third phase (1976-1979), the focus was widened to include livestock and health. Simultaneously, increased attention was paid to infrastructure. The fourth phase was a period of consolidation of all the components into a fully integrated programme. See Kinsey, "Growth, Equity and Integrated Rural Development"; Government of Malawi, Lilongwe Rural Development Project: Progress Report up to March (Zomba, 1983).

44. MNA, Box 9/8, Guide to Agricultural Production 1967/68, Department of Agriculture, Extension Aids Branch.

45. Kinsey, "Growth, Equity and Integrated Rural Development". 
new, but at this juncture agricultural extension services became greatly intensified within the project area. During the first 5 years, there was I extension worker to 200 farmers, which was 5 times greater than the average in Malawi at that time. In 1972, the ratio was reduced to I to 500 farmers, but this was still about 3 times the average. Market depots were also constructed throughout the area within a 2.5 -mile range of the depot. ${ }^{46}$

\section{LIMITS TO INTENSIFICATION}

In 1972 the Programme Manager of the LLDP, A.M. Mercer, reported, with great satisfaction, that yields of maize were well above the projected increase, i.e. $\mathrm{I}, 850 \mathrm{lb}$ per acre compared with a projected $\mathrm{I}, 400 \mathrm{lb}$ per acre previously. Furthermore, yield studies conducted by the Evaluation Unit showed that yields of all different varieties of maize (including the local variety) had increased. ${ }^{47}$ Groundnut yields were more disappointing, declining from $500 \mathrm{lb}$ to $380 \mathrm{lb}$ per acre. The official explanation for the decrease was the widespread incidence of rosette disease.$^{8}$ Thus, in general terms, it initially seemed as if both the propaganda for the early preparation and planting of gardens and the use of fertilizers had a positive effect.

Soon, however, developments seemed to be far from promising. Figures 3 and 4 reveal how yields of maize and groundnuts never reached the projected levels but fluctuated around low levels. Unfortunately, there exist no reliable yield surveys for tobacco because of difficulties in developing an accurate method of measuring. ${ }^{49}$ Data for 1972-1975 show that yields were slightly

46. MNA, Box 2 г/8/o, III, Background paper for LLDP, Phase IV, enclosed in a letter from Programme Manager A.B. Standen to Secretary for Agriculture and Natural Resources, 4 November 1979; Box I4/20/1 3/38, II, Letter from the Secretary for Agriculture R. Nec to the Secretary for Trade and Industry, 6 March 1972; 9.2 I.RK. Speech written by the Chief Land Development Officer Mr Nottidge enclosed in a circular from the Chief Land Development Officer to the Secretary for Economic Affairs, 22 June 1968.

47. MNA, Box 2I/8/7, II, LLDP Quarterly Report July-September, enclosed in a letter from the Secretary for Agriculture and Natural Resources A.C. Shaba to the Secretary to the Treasury, 3 I January 1978.

48. Government of Malawi, Lilongwe Land Development Program: Groundnut Yields 1972/73 (Zomba, I973).

49. Yields of groundnuts and maize were obtained by harvesting all plots within a yield subplot. This method was not suitable for tobacco since harvesting was often spread over a considerable period. Leaves of the yield subplot had to be stored separately in the curing barns, with additional recordings made after curing in order to arrive at an estimate of the yield of cured leaf per acre. Tobacco yields were obtained through a call-back programme during the marketing season, with attempts to cover sales of registered and unregistered growers and sales to markets others than those operated by the Agricultural Development and Marketing Corporation (ADMARC). The data were then compared with acreages under tobacco cultivation on the farmers' gardens sampled. See MNA, Box I $4 / 20 / 13 / 7$, A Survey of Tobacco Production in the Lilongwe Land Development Programme Area, Evaluation Section. 


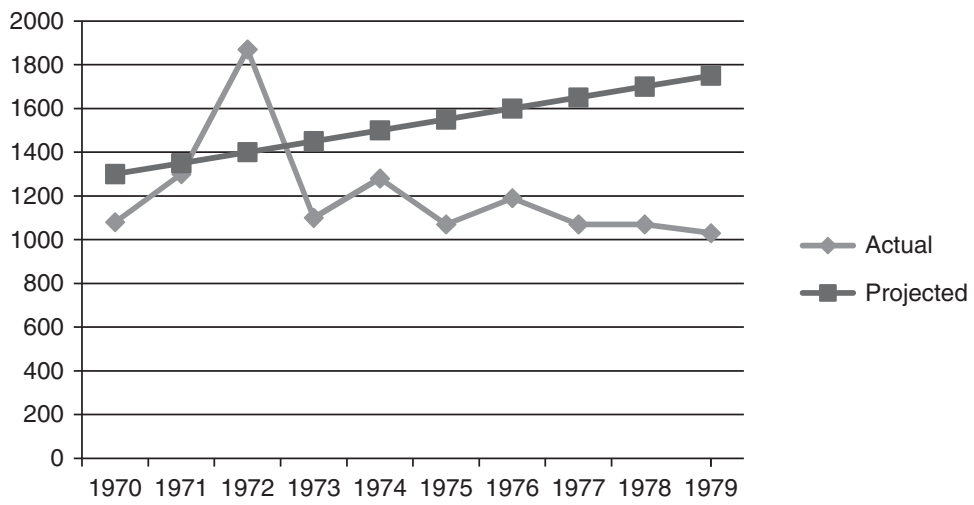

Figure 3. Actual and projected maize yields, 1970-1979. Projections based on average yields of both local and high-yielding varieties of maize.

Source: Kinsey, "Growth, Equity and Integrated Rural Development".

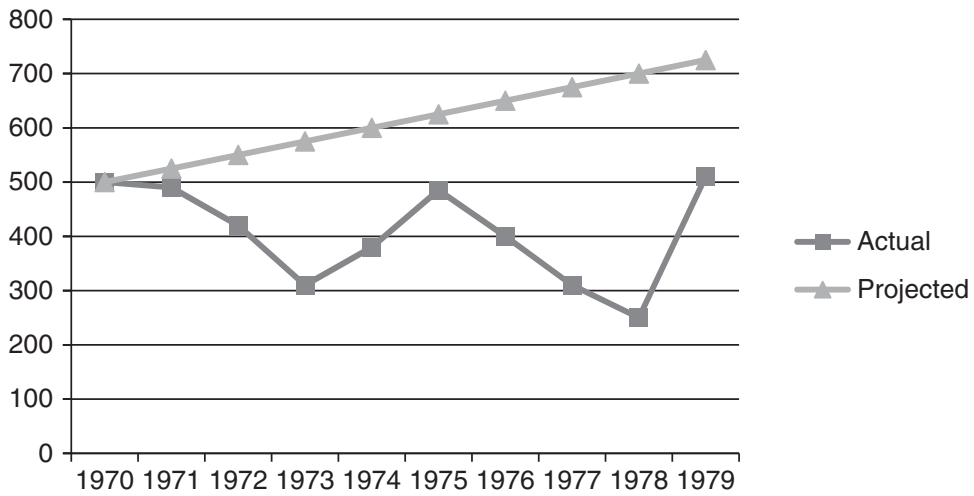

Figure 4. Actual and projected groundnut yields, 1970-1979.

Source: Kinsey, "Growth, Equity and Integrated Rural Development".

higher than projected (Figure 5), but the figures should be treated with great caution. A major problem was posed by the unregistered growers. ${ }^{\circ}$

50. In 1968, following two years of "overproduction" of tobacco, it was decided to introduce a strict production quota. The quota varied from a minimum of $250 \mathrm{~kg}$ to a maximum of $\mathrm{I}, 000 \mathrm{~kg}$. In a survey conducted two years later, it was found that there was no consistent relationship between quotas and packets of tobacco seed offered by the ADMARC or between quotas and packets of seeds received by registered growers. The records show that of the packets distributed by the ADMARC, 73.6 per cent of the recipients planted their whole quota of seeds, I 4.4 per cent planted less, while I I.9 per cent planted more. In the light of the discrepancies, it was thus concluded that farmers might have informally exchanged seeds among themselves, which, as will be shown below, played an important de facto role in the expansion of tobacco 


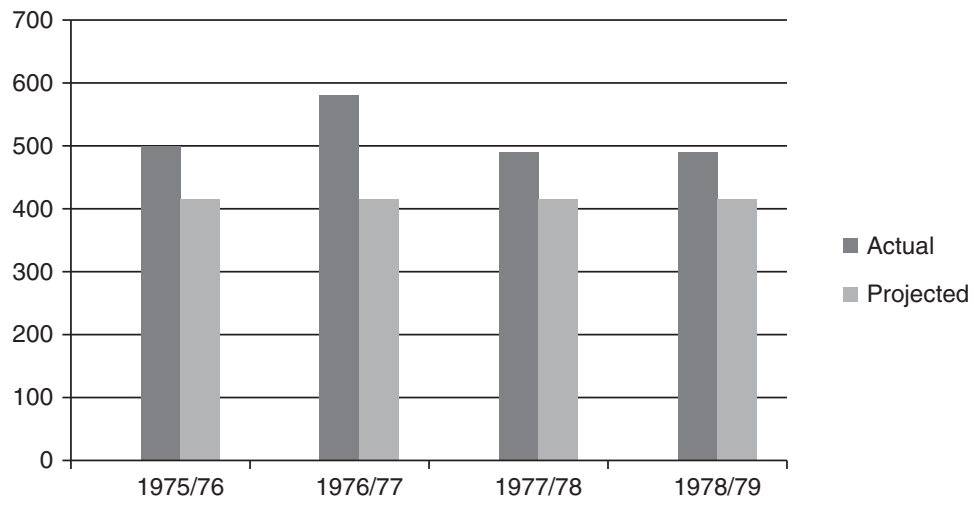

Figure 5. Actual and projected tobacco yields, 1975/76-1978/79.

Source: World Bank, "Project Performance".

Other data confirm the view that the LLDP failed to meet its goals. The acreages devoted to groundnuts and hybrid maize declined by 6 and 57 per cent respectively between 1973 and 1978 . In comparing the two crops that were not targeted, local maize and tobacco, acreages increased by 23 per cent between 1973 and 1978 for the former, while acreages for the latter showed an increase of 60 per cent. The same trend can be seen regarding purchases. In 1979 the Agricultural Development and Marketing Corporation (ADMARC), which was responsible for the purchase of all crops grown by peasant farmers, purchased 300,000 short tons of maize compared with the projected 900,000 short tons. In comparison, the actual sales of tobacco in the same year were reported to be I20,000 short tons compared with a projected i 5,000 short tons. ${ }^{5 \mathrm{I}}$ Taken together, the data indicate that there was a bias in the allocation of land and labour towards cultivating local maize and tobacco production to the detriment of the crops targeted.

The project management had several ad hoc explanations for these results. Regarding groundnuts, the plant diseases rosette and fusarium, as well as poor rainfall, were often blamed. The low yields of hybrid maze were commonly explained by delays in the distribution of credit packages. ${ }^{52}$

cultivation. See Simon Thomas, "Economic Developments in Malawi Since Independence", Journal of Southern African Studies, 2 (1975), pp. 30-5 I, 37; World Bank, Project Performance, p. 29; MNA, Box 9.19.IF, Survey of Tobacco Nurseries Practices, Lilongwe Land Development Programme: Evaluation Unit. In addition, in a socio-economic survey carried out in 197226 per cent of the farmers sampled who cultivated tobacco had no quota. See Government of Malawi, A Socio-Economic Survey of Agriculture in the Lilongwe Land Development Programme Area 1971/72 (Zomba, 1972).

5. Kinsey, "Growth, Equity and Integrated Rural Development".

52. Government of Malawi, Groundnut Yields; Kinsey, "Growth, Equity and Integrated Rural Development". 


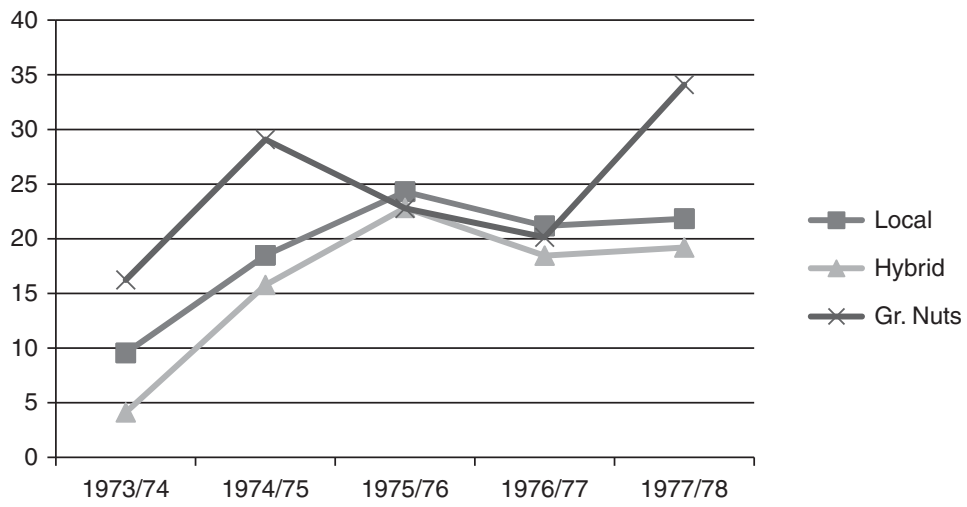

Figure 6. Gross margins per acre for local and hybrid maize and groundnuts, 1973/74-1 977/78. Source: Kinsey, "Growth, Equity and Integrated Rural Development"; World Bank, "Project Performance”.

A more comprehensive critique came from the World Bank, which blamed the government for being "very reluctant to utilise price policy as a means of increasing production and bring about a change in the relative importance of crops away from tobacco and towards maize and groundnuts". 53

Calculations made by Kinsey support the view held by the World Bank. Kinsey calculated the cost of cultivation for local and hybrid maize as well as groundnuts in $1973 / 1974-1977 / 1978$ to assess the gross margin per acre based on farm-gate prices (see Figure 6). ${ }^{54}$ The assessments must be treated with a degree of caution since it is believed that they underestimated costs, as it was assumed that farmers did not pay for additional labour. Assuming that the calculations give at least a reasonable indication of production costs, the figures reveal that during this limited period the gross margins per acre were slightly higher for local maize compared with hybrid varieties. Additionally, local maize milled better through hand pounding, stored better than other varieties, and provided more flour per shelled maize than the hybrid variety. ${ }^{55}$ Hence there were few, if any, incentives for farmers to change crops. There is also a positive correlation between the gross margin per acre and sales of groundnuts, and the few figures available for tobacco also indicate that relative prices mattered. ${ }^{56}$

The evidence seems to suggest that relative prices created incentives for farmers to continue to focus mainly on the cultivation of local maize and

53. World Bank, Project Performance, p. 7.

54. Kinsey, "Growth, Equity and Integrated Rural Development".

55. Spring, Agricultural Development and Gender Issues, p. I 3 I.

56. The only calculation for tobacco based on production costs is from $1977 / 1978$, and it shows much higher returns, at 46.82 kwacha per acre; World Bank, Project Performance, p. 45 . 
tobacco. It explains why there was no shift in crops cultivated, but relative prices alone cannot explain the failure to increase yields. Instead, we have to turn to the question of labour.

\section{MULTIPLE CONSTRAINTS AND FAMILY LABOUR}

The basic strategy of the Lilongwe Land Development Programme was to increase yields through labour-intensive measures. It was argued that this would be achieved through early planting, careful weeding, and correct spacing. In addition, hybrid maize required fertilizing, shelling, and bagging, which would be provided at a subsidized price. The aggressive marketing of groundnuts and maize would have had the effect of maintaining the value of labour. All this seemed reasonable in times of increased land scarcity. Population pressure had led farmers to engage in more labour intensive agriculture based on annual cropping. Many farmers were also forced to open new gardens in less fertile areas. ${ }^{57}$ Supplies and productivity of labour did not cause any great concern to the project management. There is no data on labour productivity. However, given the technology used it is reasonable to assume that it was low. The LLDP surveys from I974/1975 showed that the average farmer used only an iron hoe and an axe in the process of cultivation. Only i I per cent had access to work oxen, while a mere 5 per cent had access to a plough. ${ }^{8}$ Given this, a large supply of manual labour was a crucial factor in determining actual levels of production.

Early planting of local maize and groundnuts was regarded by the agricultural staff as being the most important step to increasing crop yields. Extension workers advised farmers to prepare groundnut and maize gardens in August and plant in November. Weeding for both crops was supposed to take place in December and January. Farmers normally began with maize gardens, as maize was the staple crop. Often, the gardens were not cleared before late September, which was more than a month later than recommended.59 Groundnuts were planted even later; the actual sowing time depended very much on the level of competition for labour in maize cultivation. On some occasions, groundnut gardens were not prepared before January. ${ }^{60}$ Similarly, the weeding of groundnuts did not begin until work had been completed on the maize gardens. ${ }^{6 \mathrm{I}}$ This was the opposite of what the extension workers had advised.

57. Reader, A Socio-Economic Survey of Agriculture.

58. MNA, Box I4/20/1 $3 / 7$, Survey of Smallholders within the Modul Size Range, $1974 / 75$, enclosed in a letter from the Programme Manager, LLDP, P.J. Scott to the Secretary for Agriculture and Natural Resources, 30 August 1976.

59. Spring, Agricultural Development and Gender Issues, pp. I33-I34.

60. MNA, Box 16/4/B, Monthly Extension Report, January 1968.

6. World Bank, Project Performance, p. 6. 
Initially the project management believed that the reluctance to plant early was due to lack of knowledge among the farmers. However, in a I97I/1972 survey on agricultural practices it was found that a majority of the farmers (77 per cent) were well aware of the advantages of early preparation and planting. ${ }^{62}$ Instead, farmers hesitated to follow the advice given owing to labour shortages. Village Headman Bauti Makunji remembers that:

We were sent to jail when we resisted early planting in the 1950s. In the 1970s things had changed and Dr Banda allowed us to make our own decision, so we continued the old practices of planting in October. We were very busy in those days and we just did not have the time to start earlier. ${ }^{63}$

Makunji's comments indicated that labour was a scarce resource, which seems paradoxical given the low land-labour ratios.

A useful point of departure in understanding this is the paradox observed by Alwang and Siegel that farmers in the populous southern region of Malawi tended to neglect their fields despite the relative abundance of labour. This, they argued, was because farmers were facing multiple constraints, which implies that existing farming methods cannot be understood solely in terms of factor endowments. Lack of capital caused farmers to prefer to focus their energies on off-farm work, which was a much more reliable source of income compared with agriculture. ${ }^{64}$ Meanwhile, the engagement in off-farm work created labour shortages. This was evidenced in late land clearing, late planting, and insufficient weeding. The strategy to engage in off-farm work has also been noticed in several cases in colonial Africa throughout the twentieth century and in more recent times. ${ }^{65}$ Snyder, for example, observed processes of deintensification of land use among the Iraqw in Tanzania in recent decades despite labour availability caused by a shift in labour allocation from farm to off-farm activities. ${ }^{66}$ It was more secure to invest labour in off-farm sectors than in the unreliable agricultural sector.

62. Lilongwe Land Development Programme, Evaluation Section, Agricultural Knowledge of Smallholders (Zomba, 1972).

63. Group discussion with eighteen village headmen, Extension Planning Area [hereafter, EPA] Mkwinda, 9 June 2007.

64. Jeffrey Alwang and P.B. Sigel, "Labor Shortages on Small Landholdings in Malawi: Implications for Policy Reforms”, World Development, 27 (I999), pp. I46I-I475, I463, I472. 65. Gareth Austin, "The Emergence of Capitalist Relations in South Asante Cocoa-Farming, c. 1913-33", Journal of African History, 28 (1987), pp. 250-279; Berry, No Condition is Permanent, pp. I35-158.

66. K.A. Snyder, "Agrarian Change and Land-Use Strategies among Iraqw Farmers in Northern Tanzania”, Human Ecology, 24 (1996), pp. 315-340, cited in Lowe Börjesson, A History under Siege: Intensive Agriculture in the Mbulu Highlands, Tanzania, 19th Century to the Present (Stockholm, 1994), pp. 122-123. 
Following Alwang and Siegel's method of identification, signs of seasonal labour shortages in Lilongwe district were revealed. As far back as the I950s, farmers resisted the laborious work of annually creating ridges, and seldom engaged in early planting. ${ }^{67}$ These shortages were an effect of engagement in off-farm sectors. Reports issued for the period I97I/1972 indicated that the percentage of households being headed by females, owing to the absence of men, ranged from 20 per cent to, in some cases, over 35 per cent. Approximately io to is per cent of the men were likewise absent on a daily basis, working as day labourers in Lilongwe Town. ${ }^{68}$ The possibilities for farmers to combine farming with off-farm work helped them to generate incomes, but also increased the opportunity costs of employing family members for farm work. The supplies of farm labour were thus lower than factor ratios reveal, and hence explain why farmers claimed that "I could not manage because of labour shortages", and "My husband who earlier assisted me now spent most of his time in Lilongwe". ${ }^{69}$

Part of the problem can therefore be explained by the notion of multiple constraints caused by the relatively widespread engagement in off-farm employment. At the same time, the LLDP led to an increase in the number of market depots created, which reduced transportation costs and enabled more farmers to sell part of their traditional crops on the market. This lowered the opportunity cost of mobilizing family members for farm work and hence eased the multiple constrains. As shown below, this was reflected in an increasing number of farmers shifting from off-farm work to agriculture. Yet its effects on supplies of family labour remained restricted. The LLDP lowered the cost to farmers of investing in commercial agriculture, but it did not ease the risks associated with the enterprise. The latter meant that the incentives to shift from off-farm to farm work remained partial. Furthermore, even if the sources indicate a continuation of labour shortages, those shortages explain only the absence of sufficient family members prepared to work on the farms. Farmers could theoretically respond to this by intensifying the use of non-family members.

\section{LABOUR AND DIFFERENTIATION}

Although the information regarding rural differentiation in the area is relatively scant, for the period under investigation it is nevertheless much better than for Malawi in general. Jonathan Kydd provides the best source. He used the Farm Management Surveys carried out by the Evaluation Unit

67. MNA, Box 9/8, Lilongwe District Agricultural Report, 1966.

68. Reader, A Socio-Economic Survey of Agriculture.

69. Kanyoza Chimalizeni, EPA Ukwe, i I June 2007, and Natchowa Mtuwitsa, EPA Malingunde, I6 June 2007. 
in 1969-1970 and compared those with a survey for $1978-1979 .{ }^{70} \mathrm{He}$ identified five groups of farmers that differed in terms of land size, crops grown, and types of labour used. Those categories do not automatically correspond to any theoretical concept of class, at least not in the Marxist sense of the concept. ${ }^{7 \mathrm{I}}$

The poorest group identified by Kydd used most of their land and labour for the cultivation of local maize, while the second poorest group, in addition to procuring maize, also extended their efforts into the cultivation of groundnuts. Neither group used hired labour to more than a minimal extent. It was relatively common for these farmers to perform off-farm work as well as to be employed as casual labour on the larger farms. In the middle group, farmers utilized more land and labour for cash crops. They planted improved varieties of groundnuts and combined offfarm work to increase their income.

The last two groups were the relatively better off; they shared a commitment to tobacco production and did not engage in off-farm work. The difference between the groups is characterized by the degree to which hired labour was employed: in the richest group I 6 per cent of the work was carried out by hired labour, while in the second richest group the corresponding figure was only 6 per cent. ${ }^{72}$ Kydd found that the key differences among the groups did not change much between the two periods studied. A notable exception was that the two richer groups allocated increased resources to tobacco production and that by 1978-1979 the poorer groups had replaced casual employment in the commercial production of local maize. ${ }^{73}$

In sum, the most important dividing line between the groups was the combination of two elements: the amount of resources allocated to tobacco production and the extent to which wage labourers were used. During the programme, the wealthier groups increased the amount of land and labour devoted to tobacco production. The problem with Kydd's findings is that they take only family and wage labour into account,

70. The scope and quality of the data collected for the Farm Management Surveys were better than those collected for the other evaluations conducted as part of the LLDP. Agricultural and non-agricultural income was collected on a daily basis for 12 months. In previous evaluations, agricultural income was tentatively estimated by multiplying estimates of crop production by what were believed to be the relevant prices; Kydd, "Policies Towards Peasant Agriculture", pp. 22-23.

7I. Ibid., p. 37. It has been convincingly argued that it is difficult to employ such methods because of the relative absence of private property and the role of family heads in controlling family labour. Those are two factors that have prevented the creation of "neat packages of classes"; Pauline Peters, "Inequality and Social Conflict Over Land in Africa”, Journal of Agrarian Change, 4 (2004), pp. 269-3I4, 285 .

72. Kydd, "Policies Towards Peasant Agriculture", pp. 40-44.

73. Ibid., pp. $48-49$. 
while fieldwork in Lilongwe has revealed the existence of additional arrangements.

\section{SHORTAGES OF CASUAL AND PERMANENT LABOURERS}

In line with Kydd's findings, oral information reveals that most farmers deployed casual labour paid in kind (dima), while casual labourers paid in cash (ganyu) were hired mostly by the group of farmers that cultivated tobacco. Dima and ganyu were deployed for garden preparation, planting, and harvesting. ${ }^{74}$ These were the tasks that had the most significant effects on yields.

The LLDP created new opportunities for farmers to engage in commercial agriculture by creating access to credit, inorganic fertilizers, new crops, and infrastructure. Not everyone gained from this. Kydd has shown that the programme failed to reach the poorest group, categorized as farmers who grew mostly for subsistence and employed almost no additional labour. ${ }^{75}$ Yet more people than earlier invested in agriculture in general in and cash-crop production in particular. ${ }^{76} \mathrm{Kydd}$ also showed that the group that previously performed casual work now partly replaced that source of income by increasing the cultivation of maize to be sold on the local market. ${ }^{77}$

All those changes seem to have had a notable effect on supplies of labour prepared to provide casual labouring. Village Headman Chiomba summarized it by claiming that "Dima almost disappeared because people were busy with their own work" ${ }^{78}$ Farmers found it increasingly difficult to find enough labourers. Robert Namekalimadzi remembers how in the I960s he regularly employed casual labour paid in kind. They helped him to prepare his maize and groundnut gardens. The practice continued in the I970s, but it became more difficult to find enough labourers. By the mid-I970s he decided to reduce the acreage devoted to groundnuts from 4 to 2 acres because he "could not manage without further assistance". Even more interesting is his observation that "it did not matter how much food I offered, only a few were prepared to assist me on my farm". ${ }^{79}$ That

74. EPA Mkwinda, 8-ıo and I4 June 2007; EPA Ukwe, I I-I 2 June 2007; EPA Malingunde, I 5 -I 6 June 2007; and EPA Mpingu, I $5 \varnothing 17$ June 2007.

75. Kydd, "Policies Towards Peasant Agriculture", pp. 52-53. Those farmers most probably did have access to additional labour, but one cannot be certain since Kydd does not include work parties.

76. There are no figures for the number of households that got increasingly involved in cash crop production. A useful proxy though is the number of households that received credit, which increased from 656 individuals in $1968 / 1969$ to 23,450 in $1976 / 1977$; Kydd, "Policies Towards Peasant Agriculture”, p. 77.

77. Ibid., pp. $48-49$.

78. Village Headman [hereafter, VH] Chiomba, EPA Mpingu, is June 2007.

79. Robert Namekalimadzi, EPA Mpingu, is June 2007. 
observation is important as it reveals that farmers were unable to respond to the situation by increasing levels of remuneration. The seasonal nature of the demand for agricultural labour made this strategy less feasible.

As revealed above, casual labourers were used mainly for land preparation, planting, and harvesting. Those tasks demanded full mobilization of all available labour resources. Given that the crop calendar for all farms was similar, the opportunity cost of providing casual labouring on neighbouring farms was much higher than that of performing off-farm work or engaging more resources for commercial production. Off-farm work could be conducted in the dry season, when the demand for farm labour was low. It eased the potential conflict of labour allocation. The contradiction is that while the LLDP did ease the multiple constrains by providing incentives for farmers to reallocate labour from off-farm to farm work, it also reduced the supply of casual labour, which made it increasingly difficult for wealthier farmers to increase yields by employing casual labourers.

Cultivation of tobacco provides a different story. Kydd argues that access to labour rather than land was one of the crucial factors determining the amount of tobacco grown by the farmers within the LLDP area. ${ }^{8 \circ}$ Tobacco cultivation was a very laborious enterprise and demanded skilled male labourers. It was common practice for the whole family together with a few labourers to be engaged in garden preparation, planting, and weeding. However, the crucial task was that of removing the flower buds (locally known as kuthena) to prevent seed formation, and that was carried out only by men. This practice induced the plant to produce a proliferation of leaves. It had to be done carefully, since it could easily damage the quality of the crop. Men were also in charge of the laborious task of curing. ${ }^{81}$ The division of labour implied that women who grew tobacco had to have access to male labourers. It reveals men's control over capital, as they monopolized the production process of the most lucrative crop grown in the area.

As shown above, the majority of farmers who grew tobacco extensively consisted of men who were generally better off than the average farmer. They had access to working capital and could therefore employ wage labourers. This was a practice that had already begun in the I950s. Oral information provides a similar story. Of a total of seventy-one people interviewed, thirty-five were men who grew tobacco in the 1960s. Of these, thirty were employed as casual wage labourers, i.e. ganyu, while just eight were employed as permanent wage labourers. ${ }^{82}$ Yet both the use

80. Kydd, "Policies Towards Peasant Agriculture", p. 56.

8I. MNA, 3/10/46, 22.15.9R/40179, Minutes of The Tobacco Feasibility Study Round Up meeting held 19 December 1980, 20 December 1980, Record Office; VH Kumayani, Mpingu EPA, is June 2007.

82. The farmers employing permanent labourers were: VH Philimoni, EPA Mkwinda, 8 June 2007; VH Kadyazolemba, EPA Mkwinda, 8 June 2007; Edwin Maloni, EPA Mkwinda, I0 June 
of casual labourers paid in kind and of permanent wage labour would decline in the I970s.

As with dima, the utilization of ganyu depended on local market forces and was therefore affected in similar ways as a result of the new opportunities provided by off-farm work and commercial production for a larger number of farmers. There was a general decrease in the supply of labourers willing to accept casual employment. Farmers who had the means to hire labour could no longer find people willing to work for them. Duncan Maloni, who had cultivated tobacco extensively since the early i960s, recalls those paradoxical developments: "The difference between the r960s and I970s was that in I960s labourers were available but money was scarce, while in the I970s money was available but labour was scarce." ${ }^{3}$ This indicates that an increase in wages would not necessarily increase the supply of labourers. The reason, as discussed in the previous section, was the higher opportunity cost of farmers engaging in casual labour than commercial production.

Finding labourers was not the only difficulty. There was also the problem of the skulking and alcoholism that threatened the reliability of the workforce. Farmers told stories of how their employees were sometimes drunk at work, and how, on occasions, they disappeared before the work had been completed. ${ }^{84}$ It is impossible to draw any general conclusions from this piece of information. One might speculate that the people who were still prepared to perform (or without any alternative to performing) casual wage labour consisted of men and women who could not manage farming on their own due to social problems, such as alcoholism. Casual wage labour was therefore not only becoming more difficult to acquire, but also less reliable.

Apart from having casual wage labourers at their disposal, there was also a permanent labour force available to farmers which was domiciled on the farm for one to two years. In addition to paying them wages, it was customary to provide them with food and housing, which made them available at all times. Owing to those facilities, the search for labour could reach well beyond the narrow limits of the local surroundings. Theoretically then, this suggests that farmers could solve labour shortages by importing supplies of labour from outside the district. Among those farmers interviewed, only two hired permanent workers (compared with

2007; VH Chikwala, EPA Ukwe, i I June 2007; Jabesi Numeri, EPA Ukwe, i I June 2007; VH Mphamba, EPA Mpingu, is June 2007; Jecken K. Chimbalangga, EPA Malingunde, I 8 June 2007; and Mapezi Mzenzenda, EPA Malingunde, is June 2007.

83. Duncan Maloni, EPA Mkwinda, ro June 2007.

84. Edwin Maloni, EPA Mkwinda, 9 June 2007; Jacob Chaima, EPA Ukwe, I 2 June 2007; Levias Msinsamala, EPA Mpingu, I6 June 2007; and Mapezi Mzenzenda, EPA Malingunde, I9 June 2007. 
eight in the 1960s). The two were both relatively well well-off in terms of land and capital.

Jabesi Numeri had been growing tobacco since the late i950s. In the mid-1970s he cultivated ro hectares of land and used a plough, ridger, and ox cart. An average of 2 to 3 hectares were devoted to tobacco. Village Headman Mphamba had also grown tobacco since the i950s. In the I970s he cultivated 5 hectares of land, on which about 2 hectares were devoted to tobacco. Like Numeri, he owned a plough, ridger, and ox cart. ${ }^{85}$

They both tell similar stories regarding the use of permanent labourers. In the I960s, Numeri employed between three and five permanent labourers, while Village Headman Mphamba employed two to four. All the labourers were sourced locally, often within the village. However, in the I970s they found it increasingly difficult to find labourers locally. Instead, they began to travel to the neighbouring districts of Salima and Dedza. The strategy of procuring workers outside the district was a costly enterprise. Numeri recalled that he had to spend more than a week away from home before he managed to find the workers. ${ }^{86}$ The outcome was that both Numeri and Mphamba reduced the number of permanent labourers employed.

The increase in transaction costs makes it reasonable to assume that a smaller number of farmers were able to employ permanent labourers in the I970s compared with the i960s. Meanwhile, according to the available figures, there were no signs of a decline in tobacco production. On the contrary, the acreage devoted to tobacco increased; there was also a modest increase in yields. This leaves us with the problem of how to account for the paradox of a continued expansion in tobacco production despite the decline in the supply of casual labour and the increase in the costs of employing a permanent labour force. Part of the answer is to be found in the development of the informal trade in tobacco seeds between villagers which began as an unintended consequence of the introduction of tobacco quotas in 1968.

\section{TOBACCO AND CERTIFICATES}

In order for a farmer to be allowed to grow tobacco a certificate had to be obtained from ADMARC. The requirements for certification were possession or access to a minimum of 3 acres of land, and a willingness to follow the advice of the extension staff concerning the cultivation of all crops. Such advice covered early preparation, planting, correct spacing, and weeding. Once the certificate had been issued the farmers were allowed to buy the stipulated quota of seeds. If the crop was successful the 
quota could be increased. ${ }^{87}$ Failure to meet the quota on the other hand could result in the reduction of the amount of seed one was allowed to purchase. The reduction was calculated on the basis of the amount of tobacco the farmer managed to bring to the market, but the common procedure was to reduce the quota by half. ${ }^{88}$ With such a system it meant that one year's failure caused by illness in the family, failure to purchase enough chemical fertilizers, and the like would have long-term consequences for farmers' access to capital (seeds), and thereby restrict the scope for future accumulation. To avoid such a scenario it was therefore crucial to meet the quota.

It was shown above that the project management had reason to believe that an unintended consequence of the quota system was the rise of the informal trade in tobacco seeds between farmers. The existence of seed exchange was confirmed by fieldwork. There are no figures as to the extent of seed exchange, but of the forty-five farmers who grew tobacco in the I970s, eighteen did so using seed bought by someone else. ${ }^{89} \mathrm{~A}$ notable feature of the system was the extent of women's participation..$^{90}$ Officially, women were allowed to plant tobacco, but in practice certificates were seldom given to female farmers. Some women used their elder son as surrogates to obtain certificates because of the bias against women in the industry. ${ }^{9 \mathrm{I}}$ But the extensive participation of women in the informal trade also reveals that female-headed households existed that were able to access the male labour needed for topping. The most common strategy was to seek assistance from male relatives, who were employed as dima..$^{2}$ Chotola Macdonald cultivated three acres of tobacco in the I970s. She remembers that "my brother and two nephews helped me with the tobacco". Her husband was working as a tailor in Lilongwe and he occasionally sent her money, which she used to hire ganyu. ${ }^{93}$

As revealed above, Mandala discovered a similar pattern of informal exchanges of agricultural inputs in southern Malawi. Farmers who participated in the Shire Valley Agricultural Development Project began informally to trade cotton-sprayers and pesticides with each other. It was

87. World Bank, Project Performance, p. 29.

88. MNA, 3/10/46, 22.15.9R/40179, Minutes of The Tobacco Feasibility Study Round Up meeting held i9 December 1980, 20 December i980, Record Office.

89. EPA Mkwinda, 8-I0 and I 4 June 2007; EPA Ukwe, I I-I 2 June 2007; EPA Mpingu, I 5-I6 June 2007; EPA Malingunde, I 8-20 June 2007.

90. All the tobacco-growing women interviewed (7) borrowed a certificate. Interviews with Elisabeth Zakeu, EPA Mkwinda, 8 June 2007; Vellina Njerwa, EPA Mkwinda, 8 June 2007; Yelena Office, EPA Mkwinda, I4 June 2007; Lucy Steward Mthinda, EPA Mkwinda, io June 2007; Kanyoza Chimalizeni, EPA Ukwe, I 2 June 2007; Selina Matbeka, EPA Ukwe, I 2 June 2007; and Natchowa Mtuwitsa, EPA Malingunde, 20 June 2007.

9I. VH M’bwatalika, Mpingu EPA, is June 2007.

92. VH Kumayani, Mpingu EPA, is June 2007.

93. Chotola Macdonald, EPA Malingunde, 20 June 2007. 
mostly the richer farmers who sold or leased inputs to their poorer neighbours. ${ }^{94}$ Mandala argues that this was part of a strategy to reduce risk in times of low producer prices and uncertain weather conditions. Yet the practice in Shire Valley differed in some crucial respects from the seed exchanges in Lilongwe.

First, a notable feature of the system in Lilongwe was that the seeds were not exchanged for money. Farmers who knew they were going to fall short of their production quota, whether because of labour shortage or illness, turned to free seed exchange with farmers who did not own a certificate. Noncertified farmers cultivated the crop on their own land and gave it to the owner of the certificate, who then sold the crop; the two parties shared the profit. The income retained by the certificated owner differed from case to case depending on the proportion of the crop marketed that had actually been grown by the lender of the certificate. No farmers recalled having received less than the market price for their share, although the certificate holder was not always trusted. The seed lender often accompanied the certificate holder to the market to ensure "he would not lie about the price received". 95

Could the trade in tobacco seeds be conceived of as a labour arrangement? At first glance it seems as if the system, in all its varieties, could be described as a form of sharecropping, since seeds were exchanged for labour and the two parties shared the profits made. Traditionally, neoclassical and Marxists economists have regarded sharecropping as an inefficient, exploitive, and transitory form of labour arrangement. ${ }^{96}$ Yet sharecropping has remained widespread. This has prompted a revision of how the system is viewed, as many institutionally oriented economists and economic historians currently claim that sharecropping provides an advantage to the landlord as it reduces risk (in the absence of a cropinsurance market) and minimizes supervision costs. ${ }^{97}$

Was the transition towards the new form of exchange a strategy to reduce risk and supervision costs? The answer is partly yes. In light of the increased difficulties in controlling casual labour, the system seemed to be a rational response to reduce supervision costs. It was also a strategy to reduce risk. Not because of fluctuating prices. The price of tobacco was fixed, and farmers knew in advance what they would receive. In addition, and as Figure 7 shows, prices increased between 1972 and 1977, which meant that the need to allow employers to bear a larger portion of the risk must have been

94. Mandala, The End of Chidyerano, p. is6.

95. VH Bauti Makunji, Mkwinda EPA, 9 June 2007.

96. M.G. Quibria and Salim Rashid, "The Puzzle of Sharecropping: A Survey of Theories", World Development, I 2 (1984), pp. I03-I I4.

97. Austin, Labour, Land and Capital in Ghana, pp. 4I 2-424; Keith Griffin, Azizur Rahman Kahn, and Amy Ickowitz, "Poverty and the Distribution of Land", Journal of Agrarian Change, 2 (2002), pp. 279-330. 


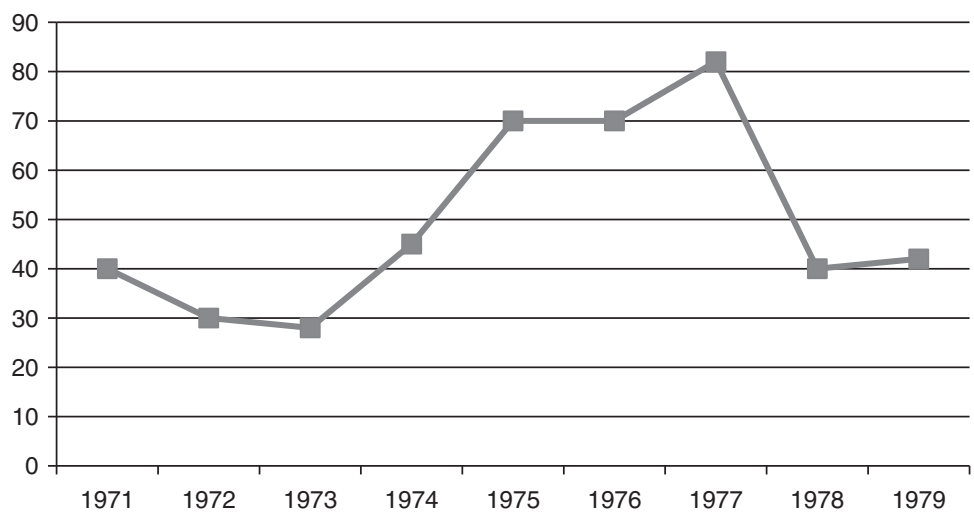

Figure 7. Prices of tobacco (northern division) in tambala per lb, I97I-1979.

Source: MNA Public Library, Government of Malawi, Economic Report 1972-1980 (Zomba, 1972-1980).

insignificant. Instead, it reduced the risk of a quota shortfall in a context where labour shortages and supervision costs were high. As shown above, the effects of not meeting the quota shortfall were severe and long-term. By allowing a reallocation of capital where it could be more productively used, certificate holders secured not only short-term but also long-term accumulation.

Classic sharecropping systems, whereby the parties consisted of a landlord and tenant, did not develop simply because the number of people depending on casual labour was declining. It was therefore not a process whereby wage labourers became sharecroppers, but one where free farmers reached an agreement. The certificate holders secured long-term accumulation and those without a certificate gained access to capital (seed). It became a functional response to the decline in capitalist relations, but it was not developed purely as a logical consequence of that decline.

\section{COLLABORATIVE LABOUR ARRANGEMENTS AND RECIPROCITY}

Farmers could theoretically respond to the difficulties and increased costs associated with the mobilization of casual and permanent wage labourers by intensifying the use of collaborative labour arrangements. Collaborative labour regimes are arrangements based on mutual contracts between relatives, friends, or, in some cases, whole villages. The role and dynamics of collaborative labour regimes have been extensively debated. ${ }^{9}$ Previous

98. Charles J. Erasmus, "Culture Structure and Process: The Occurrence and Disappearance of Reciprocal Farm Labor”, Southwestern Journal of Anthropology, I 2 (1956), pp. 444-469; Peter Geschiere, "Working Groups or Wage Labour? Cash Crops, Reciprocity and Money among the 
studies have pointed to collaborative labour regimes as a preliminary stage towards wage labour, or, as Erasmus wrote in 1956, "Throughout the world the employment of wage labor is replacing or has already replaced older reciprocal forms of farm labor". ${ }^{99}$

More recently, economic historians have questioned this linear view and revealed cases where increased cash-cropping was accompanied by an extensive use of collaborative labour regimes. ${ }^{\mathrm{I}}{ }^{\circ}$ Collaborative labour arrangements and wage labour should not necessarily be treated as mutually exclusive concepts. In his discussion of the expansion of commercial production in West Africa from the late nineteenth century to the I930s, Tosh has argued that in some locations work parties were transformed into quasi-wage-labour arrangements due to increased differentiation. This happened in cases where beer and food were regarded as a sort of payment. In situations where beer and food were of only symbolic value and the exchange of labour was regarded as the real reward, work parties showed greater resistance to social differentiation. ${ }^{\text {Ior }}$

In an African context it is often pointed out that collaborative labour regimes have played a decisive role due to the high land-labour ratios, which prevent the rise of a class of landless labourers ready to be employed as wage workers. ${ }^{102}$ The key aspect here is to what extent reciprocity was applied. Reciprocity implies that labour is exchanged for labour. As a host you were obliged not only to provide food and drink, but to volunteer at future parties arranged by the workers attending. It enabled farmers who lacked the means to pay for labourers to attract additional workers nonetheless. For the same reason, reciprocal work parties were less sensitive to fluctuations in the local supply of labourers and it was thus an effective arrangement in times of labour shortages. Using the increased cash-crop production in Asante in Ghana during the late nineteenth and early twentieth centuries as an example, Austin has argued that reciprocity was a crucial institution in areas of labour scarcity and where everybody has access to land. ${ }^{103}$ In addition, work parties also enabled farmers to access a relatively large amount of labour for a limited period of time. It made them very suitable for tasks where timing was

Maka of Southeastern Cameroon", Development and Change, 26 (1995), pp. 503-523; J.P. Moore, "Co-operative Labour in Peasant Agriculture", Journal of Peasant Studies, 2 (1975), pp. 270-291; K. Swindell, Farm Labour (Cambridge, 1985 ).

99. Erasmus, "Culture Structure and Process", p. 444.

ı००. Geschiere, "Working Groups or Wage Labour?".

I0I. John Tosh, "The Cash-Crop Revolution in Tropical Africa: An Agricultural Reappraisal”, African Affairs, 79 (1980), pp. 79-94, 87.

I02. Mahir Saul, "Land Custom in Bare: Agnatic Corporation and Rural Capitalism in Western Burkina”, in Thomas J. Bassett and Donald E. Crummey (eds), Land in African Agrarian Systems (Madison, WI, 1993), p. 76.

I03. Austin, Labour, Land and Capital in Ghana, p. 409. 
central. Weeding was such a task, conducted during the rainy season, often interrupted by heavy thundershowers.

Collaborative labour arrangements played a crucial role for farmers in Lilongwe west. As a matter of fact, the most common arrangement for farmers in the area to access additional labour was through work parties, known locally as chiwira. Women and men told neighbours and relatives that they would be invited to a feast in exchange for one or two day's labour in the host's gardens. Of the farmers interviewed, all except one (see below) depended on work parties on an annual basis. It is far from clear though to what extent reciprocity was a crucial aspect of the existing work parties. Some farmers claimed that the incentive to assist lay in the fact that food and beer were provided. Kanyoza Chimalizeni, for example, recalls how the work parties were "social gatherings where everyone in the village feasted on beer and meat". ${ }^{04}$ Others pointed to the importance of reciprocity. Selina Matbeka states that: "The only reason I joined work parties was to ensure future assistance". ${ }^{\text {IOS }}$ For her, the actual feast was of no importance. She joined the parties solely for economic reasons. Selina Matbeka was a poor farmer who lacked the means to pay for additional labourers. Her husband died in the late I960s, leaving her a widow with four children. She cultivated local maize and groundnuts on 3 acres of land. The money she made from selling part of the groundnut harvest was used to pay for consumer items, such as soap and salt. Kanyoza Chimalizeni, on the other hand, cultivated so acres of land. He valued work parties, not only as social gatherings but also as an important source of labour. Yet they were not his only source of additional labour. He also employed casual labourers, who were paid in kind or in cash using money derived from sales of tobacco and high-yielding varieties of maize.

One way tentatively to assess the role of reciprocity in the contracts is to adopt Kuckertz's distinction between the different parties. In his discussion about work parties in Mpondoland (Transkei, South Africa) he argued that a distinction should be made according to the size of the party. Festive parties tended to gather so many people that they left one pondering the viability of reciprocity for the future. ${ }^{106}$ Farmers in Lilongwe recall that the festive parties sometimes attracted as many as 100 people. ${ }^{107}$ It therefore seems reasonable to assume that reciprocity was not the key aspect underlying those parties. Other factors, such as social position and networks, were equally helpful in mobilizing people for the larger parties. Those two factors

I04. Kanyoza Chimalizeni, EPA Mkwinda, 9 June 2007.

I05. Selina Matbeka, EPA Ukwe, I 2 June 2007.

I06. H. Kuckertz, "Organising Labour Forces in Mpondoland: A New Perspective of Work Parties", Africa: Journal of the International African Institute, 55 (1985), pp. I I 5-132, I I9.

ı07. Robert Kalimdazi, EPA Mkwinda, 9 June 2007; and VH Kulamayani, EPA Mpingu, Is June 2007. 
were not mutually exclusive. In the cases of Kenya and Ethiopia, Watson has observed that the amount of labour a household could recruit depended partly on both reciprocity and social position. ${ }^{\text {I08 }}$

Yet there are indications that the role of reciprocity strengthened during the LLDP. An illustrative example is provided by Kanyoza Chimalizeni, who had stated that he regarded work parties as social events. To a question about how often he attended work parties in the I970s he replied:

Chiwira became more common in the I970s, at least for me. It was not like the old parties, whereby a lot of people joined to work and feast on beers and goat meat. The parties in the I970s were much smaller. I, my relatives and a few neighbours helped each other in the gardens. We could for example, gather and work in my neighbour's garden. Then we feasted, but the following day we went and worked together in my garden. ${ }^{109}$

Kanyoza Chimalizeni's story reveals that the work parties were undergoing changes in the I970s. Following Tosh's dynamic conceptualization of work parties, in this context of a decreasing labour supply, it seems plausible to assume that parties where reciprocity was not a key factor would diminish in the I970s. This does indeed seem partly to have been underway, as it became increasingly difficult to find "reliable people that would work hard", and who were not "drunk at work" for the big work parties. ${ }^{110}$ This does not necessarily mean that fewer people attended, for oral sources do not confirm such change. However, supervision costs increased and smaller parties became comparatively more important. This can be interpreted as a de facto strengthening of reciprocity in times of increasing labour shortages.

The smaller parties were not simply spontaneous gatherings where anyone came and participated. Instead, they depended on access to social networks and agreements that were reached in advance. They implied that the cost (including risk) of participation would be minimized, but also that one had to have access to such networks. Naliwekha Silya, for example, recalls that in the I970s she was unable to mobilize work parties because she had no relatives in the village and because "no one liked them". While Naliwekha Silya's husband was away in South Africa working, she was forced to stop growing tobacco owing to the lack of labour. ${ }^{\text {II }}$ The story does not reveal why she was disliked (she refused to answer this question), but it intimates that investments in social relations were necessary in order to fully utilize work parties.

108. Elizabeth Watson, "Agricultural Intensification and Social Stratification: Konso in Ethiopia Contrasted with Marakwet”, in Mats Widgren and John E.G. Sutton (eds), Islands of Intensive Agriculture in Eastern Africa (Oxford, 2004), p. 58.

ı09. Kanyoza Chimalizeni, EPA Mkwinda, 9 June 2007.

I 1 . Robert Kalimdazi, EPA Mkwinda, 9 June 2007, and VH Kulamayani, EPA Mpingu, Is June 2007.

I I I. EPA Malingunde, I6 June 2007. 
Reciprocity was advantageous in that it made work parties less sensitive to fluctuations in the local labour supply. The increased dependency on small work parties therefore helped to secure the supply of labour and continued to be an important supplement to family labour. It also helped farmers to access fairly large amounts of labour. The basic problem, as noted above, was that the most important measures to increase yields of groundnuts and maize were to prepare land and plant in time, which required access to additional labour for several days. Work parties never lasted for more than two days, and they were used mostly for weeding. The arrangements thus had only a modest impact on yields of maize and groundnuts.

\section{CONCLUDING REMARKS}

Access to labour is the most important factor determining the output of peasant farmers and hence their opportunities for long-term capital accumulation in Africa. Labour availability is, however, not solely a quantitative issue. Different labour arrangements are more or less suitable for specific tasks in the production cycle of a crop. That is why African farmers have exploited a wide range of labour arrangements.

Labour historians have shown that the history of rural labour relations cannot be grasped by simple linear models of historical change. The history of labour is much more dynamic than that. Examples from Africa confirm that view. Historians have revealed how family labour played a dominant role on peasant farms in twentieth-century Africa, but also that it has often been complemented by a wide range of other arrangements. Meanwhile, a crucial aspect of the linear model is still assumed to be valid, namely that the expansion of cash-crop production among peasant farmers in Africa led to increased reliance on casual and permanent wage labourers. It does not mean that commercial labour relations have become the most important source of labour. It does imply, however, that there is a correlation, or even a casual relationship, between cash-crop production and the use of commercial labour. The assumption is seldom investigated properly as the arguments are based on cross-sectional data.

In the present article, a longitudinal case is presented that questions this assumption of a linear development. The focus is on the Lilongwe Land Development Programme (1968-198I) in Malawi. Its major aims were to enable African farmers to increase yields and create incentives for them to shift from extensive cultivation of tobacco and local maize to that of groundnuts and high-yielding varieties of maize. The programme failed to meet its goals, because of changes in supplies of labour in general and changes in labour arrangements in particular. Increased opportunities for people to engage in commercial production were accompanied by a decline in the supply of local labourers who could be employed on a 
casual or permanent basis. Those developments made farmers increasingly dependent on collaborative labour arrangements that were subsumed to the needs of commercial agriculture by a strengthening of reciprocity in the contracts. Although adaptive, the collaborative arrangements were less suitable for achieving labour intensive productivity increases. The most important means to increase yields of groundnuts and maize were to prepare land and plant in time, which required access to additional labour for several days. Work parties never lasted more than two days and they tended to be used for weeding. The arrangements therefore only had a modest impact on yields of maize and groundnuts.

In contexts where everybody has access to land and where the agricultural season is the same for all farmers, it will always be difficult to mobilize additional labour during peak seasons. Under those circumstances, it becomes self-evident why specific processes of expanded cash crop production are accompanied by a decline in supplies of casual and permanent wage labourers. The number of people who are either willing or forced to supplement their own farming with casual labouring is significantly reduced when cash-crop production is diffused among a large number in a fairly short period of time. In the conventional linear model it is assumed that farmers will exploit commercial labour relations as soon as they have the means to so. In this, only the demand side is taken into consideration. The present article calls for a more complex understanding of agrarian change and labour relations, including analyses of the supply side and recognition of the need to combine different labour arrangements. That is why the history of labour in rural Africa will never be linear. 